Health Foundation, London, UK

Hugh.Alderwick@health.org.uk Cite this as: BMJ2021;374:n1670 http://dx.doi.org/10.1136/bmj.n1670 Published: 02 July 2021

\section{Priorities for the new health secretary}

\author{
The backlog, the workforce, social care, and tackling inequalities
}

Hugh Alderwick head of policy

England has a new secretary of state for health and social care. Sajid Javid-previously the chancellor, in charge of public finances in 2019 and early 2020-was appointed health secretary on 26 June. He replaces Matt Hancock, who resigned after images emerged of him kissing his aide Gina Coladangelo, in a breach of his own social distancing rules. Even in normal times, being health secretary is among the toughest jobs in government. Add a pandemic and the task is enormous.

Javid arrives at a precarious moment. Covid-19 cases are rising steeply ${ }^{1}$ and further easing of social restrictions is planned for 19 July. The boss of NHS England, Simon Stevens-responsible for leading much of the NHS's pandemic response-is standing down shortly after. And the government is-or at least was-soon expected to publish its health and care bill, setting out plans to reorganise parts of the NHS in England. Javid says his immediate priority is the pandemic response. ${ }^{2}$ But what should be his wider priorities as society learns to live with the virus? Four areas are particularly important.

The first is tackling the backlog of unmet need. Covid-19 led to massive disruption of NHS services. The number of people waiting for routine hospital care has now passed five million-the highest since records began-and nearly 400 ooo have been waiting over a year for treatment. ${ }^{3}$ There may be six million "missing patients" yet to be referred for elective care. ${ }^{4}$ And covid-19 is likely to create additional health needs, such as for mental health support. .-7 $^{-7}$

Activity is returning across the NHS, ${ }^{89}$ and staff have been working hard to recover services. But the size of the challenge is eye watering, and the policy response from government must grow to match it. Labour's "war on waiting" in the $2000 \mathrm{~s}^{10}$-backed by substantial increases in funding and staff-shows the scale of action needed.

The second priority is supporting and expanding the health and care workforce. Before covid-19, staffing gaps stood at around 100 ooo in the NHS ${ }^{11}$ and 122 ooo in social care. ${ }^{12}$ During the pandemic, staff have worked under incredible strain and put themselves at risk to help others, sometimes without adequate protection. ${ }^{1314}$ Social care staff have been more likely to die from covid-19 than others of the same sex and age. ${ }^{15}$ Staff are exhausted, and some feel abandoned. ${ }^{16}$ Both sectors need long term workforce strategies, supported by multiyear investment. But they currently have neither. Javid must also soon make decisions about NHS pay. NHS wages per employee fell in real terms over the past decade. ${ }^{17}$ The government's proposed $1 \%$ pay rise for staff in 2021-22 risks exacerbating staffing shortages.

\section{Support for vulnerable groups}

Adult social care in England is a third priority. The care system that entered the pandemic was a threadbare safety net, scarred by decades of political neglect and underfunding. The effect of the pandemic on people receiving care has been grim. By April 2021, there had been 27200 excess deaths among care home residents and 9600 excess deaths among people receiving care at home. ${ }^{18}$ Unmet need for care and the burden on unpaid carers-mostly women-seem to have increased. ${ }^{18}$

Fundamental reform of the system is needed to deal with the longstanding policy failures exposed by covid-19. As Javid knows, the Treasury often labels reform unaffordable. But if it chooses to, government can afford to provide fairer and more generous support for vulnerable people in society. ${ }^{19}$

The fourth priority is reducing health inequalities. Covid-19 has had a disproportionate effect on more deprived and ethnic minority groups. ${ }^{20} 21$ These inequalities are nothing new: covid-19 simply exposed existing gaps in health that were already vast and growing. ${ }^{22} 23$ The government has promised a white paper on "levelling up" and is reorganising the English public health system. But so far it has not grasped the scale of action needed to tackle health inequalities. A systemic approach is needed. ${ }^{24}$

This is another opportunity for Javid to learn from the 2000s-the last time England had a national health inequalities strategy. The approach evolved over time and combined interventions in a mix of areas-including better support for families, engaging communities, efforts to tackle poverty, improving access to NHS care, and action on underlying social and economic determinants of health-combined with increased investment in public services and social programmes. The strategy seems to have contributed to reductions in social inequalities in some health determinants and modest reductions in health inequalities over time..$^{25}$ A similar approach is now needed to guide public policy after the pandemic.

None of this will happen without additional government spending. Hope rests on Javid convincing his successor at the Treasury to substantially increase investment in health at the autumn spending review. Feels unlikely? The risk is that the most visible priorities-for instance, in NHS hospitals-are put ahead of investment in social care and wider services that shape health and inequalities. Both are needed. Javid must also give NHS leaders the backing they need to recover services. This means going with the grain of the NHS's plans to boost local collaboration while curtailing-or dropping-Hancock's misguided 
proposals to bring the NHS under closer ministerial control. ${ }^{28}$ Appointing a credible replacement for Simon Stevens is also critical to gain the trust of the service.

Competing interests: I have read and understood BMJ policy on declaration of interests and have no interests to declare.

Provenance and peer review: Commissioned; not externally peer reviewed.

1 UK Government. Coronavirus (COVID-19) in the UK. 29 Jun 2021. https://Coronavirus.data.gov.uk/

2 Department of Health and Social Care. Secretary of State for Health and Social Care, Sajid Javid, prioritises ending pandemic. 2021. https://www.gov.uk/government/news/secretary-of-state-forhealth-and-social-care-sajid-javid-prioritises-ending-pandemic.

3 NHS England. Consultant-led referral to treatment waiting times. https://www.england.nhs.uk/statistics/statistical-work-areas/rtt-waiting-times/.

4 Gardner T, Fraser C. Longer waits, missing patients and catching up. Health Foundation. 2021. https://www.health.org.uk/news-and-comment/charts-and-infographics/how-is-elective-carecoping-with-the-continuing-impact-of-covid-19.

5 Jia R, Ayling K, Chalder T, etal. Mental health in the UK during the COVID-19 pandemic: cross-sectional analyses from a community cohort study. BMJ Open 2020;10:e040620. doi: 10.1136/bmjopen-2020-040620 pmid: 32933965

6 Xiong J, Lipsitz O, Nasri F, etal. Impact of COVID-19 pandemic on mental health in the general population: a systematic review. J Affect Disord 2020;277:55-64. doi: 10.1016/j.jad.2020.08.001 pmid: 32799105

7 Strategy Unit. Mental health surge model. 2020. https://www.strategyunitwm.nhs.uk/mentalhealth-surge-model.

$8 \quad$ NHS Digital. Appointments in general practice. https://digital.nhs.uk/data-and-information/publications/statistical/appointments-in-general-practice.

9 NHS England. A\&E attendances and emergency admissions. https://www.england.nhs.uk/statistics/statistical-work-areas/ae-waiting-times-and-activity/.

10 Harrison T, Appleby J. The war on waiting for hospital treatment: what has Labour achieved and what challenges remain? King's Fund, 2005. https://www.kingsfund.org.uk/sites/default/files/field/field_publication_file/war-on-waiting-hospital-treatment-labour-full-report-johnappleby-anthony-harrison-kings-fund-4-august-2005.pdf.

11 Gershlick B, Charlesworth A. Health and social care workforce. Health Foundation, 2019. https://www.health.org.uk/publications/long-reads/health-and-social-care-workforce.

12 Skills for Care. The state of the adult social care sector and workforce in England. 2019. https://www.skillsforcare.org.uk/adult-social-care-workforce-data/Workforce-intelligence/documents/State-of-the-adultsocial-care-sector/State-of-Report-2019.pdf.

13 National Audit Office. The supply of personal protective equipment (PPE) during the pandemic 2020. https://www.nao.org.uk/wp-content/uploads/2020/11/The-supply-of-personal-protectiveequipment-PPE-during-the-COVID-19-pandemic.pdf.

14 Public Accounts Committee. COVID-19: government procurement and supply of personal protective equipment. 2021. https://publications.parliament.uk/pa/cm5801/cmselect/cmpubacc/928/92802.htm.

15 Office for National Statistics. Coronavirus (COVID-19) related deaths by occupation, England and Wales: deaths registered between 9 March and 28 December 2020

https:/www.ons.gov.uk/peoplepopulationandcommunity/healthandsocialcare/causesofdeath/bulletins/coronaviruscovid19relateddeathsbyoccupationenglandandwales/deathsregisteredbetween9marchand28december2020.

16 Health and Social Care Committee. Workforce burnout and resilience in the NHS and social care 2021. https://publications.parliament.uk/pa/cm5802/cmselect/cmhealth/22/2202.htm.

17 Health Foundation. At the start of the pandemic, NHS earnings had fallen in real terms by over £600 per employee over the last decade. 2021. https://www.health.org.uk/news-and-comment/news/at-the-start-of-pandemic-nhs-earnings-had-fallen-in-real-terms.

18 Dunn P, Allen L, Alarilla A, Grimm F, Humphries R, Alderwick H. Adult social care and COVID-19 after the first wave: assessing the policy response in England. Health Foundation, 2021.

19 Charlesworth A, Tallack C, Alderwick H. If not now, when? The long overdue promise of social care reform. Health Foundation. 2021. https://www.health.org.uk/news-and-comment/blogs/ifnot-now-when-the-long-overdue-promise-of-social-care-reform.

20 Public Health England. Disparities in the risk and outcomes of COVID-19. 2020. https://assets.publishing.service.gov.uk/government/uploads/system/uploads/attachment_data/file/908434/Disparities_in_the_risk_and_outcomes_of_COVID_August_2020_update.pdf.

21 Razai MS, Kankam HKN, Majeed A, Esmail A, Williams DR. Mitigating ethnic disparities in covid-19 and beyond. BMJ2021;372:m4921. doi: 10.1136/bmj.m4921 pmid: 33446485

22 Marmot M, Allen J, Boyce T, Goldblatt P, Morrison]. Health equity in England: the Marmot review 10 years on. Institute of Health Equity, 2020. https://www.health.org.uk/sites/default/files/upload/publications/2020/Health\%20Equity\%20in\%20England_The\%20Marmot\%20Review\%2010\%20Years\%200n_full\%20report.pdf.

23 Marmot M, Allen J, Goldblatt P, Herd E, Morrison J. Build back fairer: the covid-19 Marmot review. Institute of Health Equity, 2021. https://www.health.org.uk/publications/build-back-fairer-thecovid-19-marmot-review.

24 Dixon J, Everest G. The government's levelling up agenda. Health Foundation (forthcoming).
25 Robinson T, Brown H, Norman PD, Fraser LK, Barr B, Bambra C. The impact of New Labour's English health inequalities strategy on geographical inequalities in infant mortality: a time-trend analysis. J Epidemiol Community Health 2019;73:564-8.

doi: 10.1136/jech-2018-211679 pmid: 30890592

26 Barr B, Higgerson J, Whitehead M. Investigating the impact of the English health inequalities strategy: time trend analysis. BMJ2017;358:33310. doi: 10.1136/bmj.j3310 pmid: 28747304

27 Bambra C. Levelling up: global examples of reducing health inequalities. Scand J Public Health 2021:14034948211022428; Epub ahead of print. doi: 10.1177/14034948211022428 pmid: 34148458

28 McKenna H. The health and social care white paper explained. King's Fund. 2021. https://www.kingsfund.org.uk/publications/health-social-care-white-paper-explained. 